\title{
DEVELOPING GENDER CURRICULUM IN ISLAMIC HIGHER EDUCATION
}

\author{
Rosita Tandos \\ State Islamic University Syarif Hidayatullah, Jakarta
}

\begin{abstract}
Gender equality and justice are among the important topics to discuss not only at the practical level, but also in academic circumstances aiming to enlarge the framework and analysis of the issue. Integrating an Islamic perspective with other disciplines of study is a part of making it more applicable and down to the earth. Using a qualitative method and grounded theory approach, this study explored the point of developing a gender curriculum at Islamic Higher Education interconnected with an Islamic studies' discussion. The participants of the study were lecturers and students from different faculties (Tarbiyah, Syariah, Ushuluddin, Adab, and Dakwah). The total participants were 50 people $(n=50)$ consisting of 30 lecturers $(n=30)$ and 20 students $(n=20)$. They invited to complete a short list of close-ended questions and answer some open-ended questions covering points related to their knowledge, thoughts, and experiences, as well as topics related to designing a curriculum on gender and how to apply the gender issue. Three theoretical frameworks were used to analyze the topic and findings (Islamic perspective, gender curriculum, and community development theories). The community development approach was mainly used to explore principles and strategies that could be applied for community development to improve the implementation of the functions of Higher Education (conducting education, research, and community empowerment) and a strategic way to turn theories into practice.
\end{abstract}

Key words: Gender curriculum, topic and disain of gender curriculum, Islamic higher education, Islamic community development

\section{Introduction}

Educational institutions play an important role in preventing and addressing issues of gender inequality by integrating these issues into the teaching and learning process, their research and publications, as well as community engangement and empowerment programs provided mainly for women and girls. Such effort allows for the implementation of the functions of the Tri Dharma of Higher Education (Education, Research, and Community Service).

Improving the quality of education is a strategic step for the realization of gender equality and justice, or Keadilan dan Kesetaraan Gender (KKG), in community life. Each campus is a strategic place to develop knowledge and awareness of KKG. 
Therefore, leaders and academics need to improve the campus' atmosphere, learning process, and thinking to ensure that they are far from negative stereotypes towards women. The development of a curriculum and community development activities are strategic efforts to socialize and implement gender mainstreaming in campus life and society.

Religious universities, such as the State Islamic Institute (IAIN) of Syeikh Nurjati, have a strong and strategic role to promote a safe and peaceful place for women through comprehensive religious and cultural norms that value understanding, as well as emphasize gender equality and justice by integrating Islamic studies with other disciplines of studies.

Khotimah (2008) quotes Ahmad Tafsir from his book Philosophy of Education explaining that the curriculum is one of the main components of education that continues to be developed. The curriculum can be illustrated in three terms: first, the curriculum as the meaning of the subject; second, the curriculum can mean a course syllabus; and third, the curriculum in the sense of a study program implemented by an educational institution.

Banks, as quoted also by Khotimah (2008), describes an approach used to incorporate gender material in a curriculum consisting of: contribution approach (carried out by education systems and policies through explicit curricula, adaptive approaches (added to existing curricula without changing their structure); transformational approach (existing curriculum completely changed and replaced by gender perspective); and social action approach (making gender-sensitive decisions and actions in daily life activities in academic and social settings).

In this study, the term gender curriculum refers to the meaning that all scientifically compiled activities carried out inside and outside the class are concerned and focus on the topic and issue of KKG reflected in the objectives, content, process / implementation, stages and results of evaluation of learning and teaching proceesses. The term gender-based community empowerment is all forms of efforts, activities, or programs carried out in the community by emphasizing the active participation of women, as well as addressing problems and effective solutions for the creation of gender equality and justice (KKG) in community life.

The strategic effort that is still being carried out is through the policy of 
integrating the issue of gender sensitivity into the curriculum of Islamic Higher Education (PTAI). In this case, Islamic Higher Education of Ministry of Religious Affairs has collaborated with related parties to hold various meetings in order to strengthen the gender curriculum within the scope of PTAI. Efforts to strengthen the gender curriculum are expected to be able to develop sensitive Islamic science, responsiveness, and solutions to the problems of gender inequality and injustice.

The understanding of KKG helps overcome problems by finding effective solutions based on religious values, culture or local wisdom, as well as implementing international regulations and conventions related to Human Rights and Women's Rights. Furthermore, the concept of gender equality and justice (KKG) has implications for the awareness that women are partners and experts in resolving the problems they are facing, as well as being active agents of change in social life. This needs to be supported through cooperation and coordination among stakeholders (government agencies, NGOs, the private sector, and civil society) that need to be established and enhanced.

Community Development is an academic activity that is one form of implementing the Tri Dharma of Higher Education (Education, Research, and Community Service) which also serves as the main task of lecturers or teaching staff. Therefore, the research on the Development of Gender-Based Community Empowerment and Curriculum is expected to be a strategic first step for the implementation of gender-based scientific activities, including the preparation of a Gender Equality and Justice curriculum manual that will be used within the PTAI.

At the end, it is expected that the research findings and discussion can be disseminated through publication and implemented as an effort to educate the public, create policy changes, and improve the quality and effectiveness of programs and services available to women and society, in general. This paper covers 6 (six) main points: 1) Problems and Research Method, 2) Theoretical framework used, 3) Topics of gender and their integration with Islamic scholarship, 4) Gender teaching design, 5) Gender perspective in community development, and 6) Conclusions.

\section{Formulation of the Problem and Research Method}

This research uses qualitative methods by raising 4 (four) main research questions, namely:

- What are the main gender topics discussed in class? 
- How do you integrate science and various kinds of knowledge in gender learning?

- What are the methods or gender learning designs in the classroom?

- How is the implementation of understanding gender equality and justice in the implementation of community development programs?

The research of developing a gender curriculum in Islamic Higher Education applied qualitative methods and a grounded theories technique that aim to explore the knowledge, understanding, and experiences of informants (lecturers and students) related to curriculum issues and gender-based community empowerment. This research was located at IAIN Syeikh Nurjati Cirebon and included three faculties (UAD, Syariah, and Tarbiyah).

The data collection process involved in-depth interviews with students and lecturers. Each participant of this study attended an interview which lasted around 45 to 60 minutes. Interviews were structured and semi-structured using open-ended questions. Explanation and development of probing were done during the interview process.

The questions related to informant demographic data include data on age, gender, status, faculty, and semester, with additional questions for lecturer informants. Open - ended questions include three important points (gender learning design, scientific integration in gender learning, and the impact of gender understanding for community empowerment programs carried out by universities and academicians).

Determination of the sample was carried out with a non-random sampling technique and the sampling method used purposive sampling. The method for determining this sample was through key informants who were considered able to provide the desired information (Creswell, 2003). To ensure informants understood the research topic, the researcher firstly explained the operational definition applied in the research. There were representatives from each faculty of IAIN Syeikh Nurjati: Shariah / Law Faculty, Tarbiyah / Education Faculty, and UAD Faculty (Ushuluddin, Philosophy and Da'wah). The total number of participants was 40 people; lecturers $(n=$ $20)$ and students $(n=20)$ from several majors from these three faculties.

The process of data processing and analysis of the stages of qualitative research follow as mentioned by Miles and Huberman, namely: data reduction, data display, and data verification. Data is analyzed by making memos, interview transcripts, codes, categories, and themes of the data collected (Denzin, 2000; Lofland \& Lofland, 2005). 
These stages are carried out to sharpen the analysis of the points that become the problem in this study.

Data verification activities and data validity testing are carried out by making sure the informant answers (member-checking) to ensure that there is no misunderstanding and ensuring that important matters are included in the results or research findings. In addition, listening to expert opinions is another attempt to improve data validity (Rubin and Babbie, 2010). The next part discusses the theoritical framework used in the research to sharpen the anaysis of the collected data and the discussion of research findings.

\section{Theoretical Framework}

The research that was conducted refers to several theories, concepts, and perspectives related to the issue of Gender Equality and Justice (KKG), namely:

\section{Gender Based Curriculum}

Nowadays, gender is a discourse that creates resistance in the community; in both academic and non-academic circles. This happens because various things are not only coming from an individual, group, or community, but also from policies that tend to be gender biased. For example, patriarchal culture has been a deeply entrenched paradigm for a long time in which women are regarded as weak or second class and their position is lower than that of men.

Change agents, or agents of change, are labels embedded in the academic world. The academician can actually make changes in the community and must be done with comprehensive analysis. One of them is understanding the concept of gender correctly and fairly. Actually, the concept of gender is not only about women, but also about men. The term gender is different from sex, which refers more to biological or physical performance. It shows more about the division of roles, opportunities, and responsibilities between men and women. In optimizing the correct understanding of gender perspectives in academic discourse, gender-based planning for learning should be conducted. This learning plan we know as a curriculum.

The curriculum is a learning design to provide knowledge to all students in providing correct understanding throughout the learning process. The meaning of curriculum is made clear by Ornstein and Behar in saying that curriculum is a 
description of planned steps to achieve an institution's vision and mission. By understanding the definition of curriculum above, the term curriculum is not only intended for students, but for all academic components that work together in formulating a learning design to realize the vision and mission of the educational institution. Furthermore, the designed curriculum is based on gender, because gender discourse is a very important way of realizing equality and justice without marginalizing a certain group based on sexual differences.

The gender-based curriculum is one way to increase the sensitivity of the academic community in understanding the concept of gender and then being able to apply and socialize in the midst of society. One way to implement a gender-based education curriculum is by making relations or incorporating gender concepts throughout the scientific field. Professor Amin Abdullah states that gender discourse is a contemporary issue that is necessary to be applied as an alternative perspective and analysis for a scientific field of studies (Amin Abdullah, 2004).

For example, the curriculum for Tarbiyah faculties (based on gender analysis) is how the process of education is not biased towards gender and applies a system of equality and justice without distinguishing between men and women such as in obtaining the same education services, in giving opinions or discussing, and/or getting appropriate scores in any subjects.

Another example is in the Shari'ah faculty; for example, Islamic Economics and gender might be in the form of justice for all people, namely men and women to develop their potential or expand the economy. Then, women and men are not differentiated to access the financial resources for the sake of creating a more prosperous life. Similarly, for the faculty of Ushuluddin, Adab, and Da'wah (UAD) it is also necessary to develop a gender-based curriculum. For instance, the effort is to develop more discussion on gender and Islam (e.g. religious thought, literature, and broadcasting and development of Islamic societies).

\section{Islamic Scientific Perspective}

The application of Islamic teachings is very fundamental for a Muslim since this is related to their worship of the Supreme Creator, both when they are worshipping Almighty God and when he/she makes social relations with human beings (muamalah); including relations between men and women in the various roles and responsibilities 
that they have.

In understanding the meanings implied in the verses of the Qur'an and the Hadith texts, misunderstandings often occur when interpreting the concepts of gender equality and justice (for men and women). Islam, as a religion which is believed to be revealed as rahmat (blessing) for the entire universe, emphasizes aspects of justice, prosperity, and happiness in the lives of individuals or people. To achieve this, Islamic teachings emphasize the importance of cooperation and help between one individual and another.

Professor Nasaruddin Umar, in his book 'The Nature of Equality and Gender Justice', presents several principles of gender equality in the Qur'an. He explained that one of the goals of human creation is to worship Allah swt. (Q.S. Az-Dzariyat / 51: 56). Therefore, in the capacity of being a creation, women and men have the same opportunity to become ideal; not seeing where they come from (different ethnic groups, ethnicities, races, and nationalities).

Besides that, both parties are said to have the same responsibility as caliphs on earth (Q.S. Al-An'am / 6: 165) who are submissive, obedient, and devoted to Allah SWT. Likewise, in earning achievements, Islam does not provide a difference between men and women (Q.S.Ali Imran / 3: 195; Q.S.An-Nisa / 4: 124 and Q.S. Mu'min / 40: 40). The verses of the Qur'an imply ideal gender equality, while affirming achievement opportunities for each individual in the field of spiritual and professional careers.

From the description above it can be understood that comprehensive and holistic understanding and interpretation of religious texts are needed to answer all kinds of problems that arise due to the evolving reality of life. Of course scientific integration is needed in reviewing and offering solutions to the issue of gender inequality and injustice. For example, the interpretation of religious texts could use historical, sociological, and community development approaches that are expected to answer the problems of inequality and injustice experienced mostly by women (Mufidah, 2004), as well as increase active participation of the government and components of society.

\section{Gender-based Community Development}

The discussions of gender equality and justice (KKG) have been voiced in particular by feminist groups using different analyses and emphases according to their 
scientific backgrounds, practices, and professions. The concept of gender refers to the socially-based construction based on sex of the roles of men and women in both the public and private sphere (United Nations, Council of Economic and Social). Gender also refers to socialized identities that originate roles, responsibilities, characteristics, and behaviors associated with boys and girls, and men and women.

Feminism is also the main foundation in doing community work, specifically with community or social workers who are concerned with the issues of KKG. In this case, women are an element of society that is considered very important in encouraging efforts to resolve social problems such as poverty, education, and health. Marginalization and subordination of groups is a form of injustice that is still experienced by women in every part of the world. In everyday life, they often experience violence, stereotyping, and discrimination in accessing opportunities, facilities, and decent work.

Gender inequality and injustice in the perspective of community development could be solved through the following efforts: first, analyze the main causal factors; second, identify resources (human and natural resources) or assets available in the community; third, increase community participation and that of related stakeholders in solving the problem; fourth, create a democratic atmosphere in making decisions for the common interest; and fifth, make policy changes and improve the quality of community-based programs.

Problem analysis should analyze the structure or system that creates gender inequality. This structure is often maintained by those who enjoy the power to discriminate or exploit women, which can be present in the form of patriarchal culture, religious understanding, or gender-biased policies.

In implementing the community development efforts above, women are expected to be able to attend as partners, experts, and agents of change. They can start the effort by increasing their roles as mothers, children, friends, and relatives who will help to make a better life. Therefore, increasing the knowledge, skills, and capabilities of women is very important.

When talking about society, social transformation in people's lives needs to be a relationship or partnership for optimizing the roles of men and women. Julia Cleves Mosse, in her book entitled "Half the World, Half a Chance: An Introduction to Gender 
and Development" (which was later translated by Hartian Silawati), explained that the emergence of women as actors on the world stage is one of the most powerful dynamics in the struggle against a social order that is unfair within a nation or between nations. With the statement above, it is understood that seeing women as actors in creating change will automatically accelerate and better contribute than using only one actor; because sometimes the elements that exist in women are elements that are not in men, and vice versa.

Women and men are understood not to be completely the same, but at least there are three important aspects that need to be considered that are owned by both, namely rights, responsibilities, and opportunities so that both (men and women) can support each other and work as a team (work) and contribute to family and community life. Gender roles shape women's access to rights, resources, and opportunities. This role may vary from one context to another and, from time to time, between cultures. Furthermore, gender roles are also influenced by socio-economic, political, and cultural contexts, as well as factors such as age, race, social status, or ethnicity (Dominelli, 2000). In addition, gender differences between men and women are shaped by social and cultural constructions that are perpetuated by the interpretation of religion and myths to become like a belief (Mufidah, 2004).

Indonesia actually has a set of legal rules aimed at eliminating gender discrimination towards the presence of gender equality. Among them are Law Number 7 of 1984 concerning the Ratification of the Convention on the Elimination of All Forms of Discrimination Against Women, and Presidential Instruction Number 9 of 2000 concerning Gender Mainstreaming in National Development. In addition, the Draft Bill on Gender Equality and Justice (KKG Bill) is one of the draft legislations that is expected to become an umbrella policy in order to create a conducive situation to prevent gender discrimination.

In addition, the International Convention on the Elimination of All Forms of Discrimination Against Women (International Convention on the Elimination of All Forms of Discrimination Against Women) is a powerful instrument that binds the government and state to ensure the protection of women's rights including all forms of violence (verbal, physical, and sexual).

\section{Topics of Gender and Integration of Islamic Science}


In this first section, there are four questions which can be explained in their entirety and are classified into the following points:

\section{Important topics related to gender studies}

Gender gaps (gender inequality) occur in almost all aspects of life. For example, gender disparities in family life, gender inequality in law, gender disparity in terms of economics, politics, social culture, and education. There is even a gender gap which is a misinterpretation of the holy verses, for example the concept of ribs, the concept of inequality of men and women in the perspective of different religions, and so on; furthermore, in terms of historical aspects where gender bias and violence against women have been discussed in various scientific perspectives (e.g. Arabic, theology, jurisprudence, Sufism, Hadiths, economics, politics, etc.).

There are various gender topics that can be discussed related to integration with other sciences. Gender studies can also be discussed with various Islamic scientific perspectives. Firstly, the interpretations of the verses of the Qur'an which cover all aspects of gender include: points about leadership, inheritance rights for men and women, and the role of women in public. All of these things require interpretation of religious texts and even need to have their own subjects related to gender perspectives.

The most important integration of Islamic scientific discussions in gender studies is related to the history of how the Prophet Muhammad raised the dignity of women at that time, as well as the histories of the family and friends of the Prophet. In the history of Islam, we know the wife of the Prophet Muhammad saw. (Siti Aishah r.a) who was in a war and became a warlord. It shows that there is no gender discrimination in the name of religion in the era of Islam in the past, however there may be gender discrimination in some Islamic countries where women are kept like in a cage and not allowed to leave without being escorted by her muhrim and so on.

Islamic scholarship such as theology, jurisprudence, and Sufism can be integrated in discussing the topic of gender equality. Even other forms of Islamic scholarship such as Ulumul Quran, Ulumul Hadith, Ushul Fiqh, Interpretation, etc., can also be used to strengthen gender equality and justice issues. The Sharia faculty studies the sciences whose roots are Usul Fiqh, so the discussion of ushul fiqh should be used by other perspectives which may also be based on gender equality. Furthermore, the scientific perspective can be integrated in discussing the topics of gender equality and 
justice, starting from Philosophy, Mathematics, Biology, Chemistry, Medicine, Economics, Social Sciences, Politics, Culture, Interpretation, Hadith, History, Sociology, Anthropology, Psychology and others. Integration between general science and Islamic science is expected to be able to bring awareness of a gender perspective and can be linked, compared, analyzed, and realized using these two perspectives (Islamic and general scientific thinking).

The study of the Qur'an and Hadith that discusses the verses of the Qur'an about 'Arrijalu qawwamuna alannisa' should be clarified if the interpretation is rijal by men; meaning they are stronger than women, but if the intended word is not gender, but someone who has a high level of knowledge, this verse means a leader towards people who are from a lower scientific side. Therefore, the Qur'an and Hadith need to be interpreted according to historical facts, in line with what was done by the Prophet Muhammad and friends who, in the past, did not limit the movement of women in the domestic sector nor the public sector. Integration of the topic of $\mathrm{KKG}$ in various disciplines is needed, especially in scientific disciplines which have so far indicated that women are under or subordinated to men.

Hadith or ulumul hadith is the basis or source of Islamic teachings and scholarship. It provides references and sources for theology, jurisprudence, and Sufism. Of course, Hadith is related to all aspects of life, including relations between men and women (gender). In fact, it is suspected that there are misogynist traditions which are considered to be degrading to the degree of women which are the reason for the emergence of gender injustice in society. In terms of gender matters, the science of Hadith serves as a method of testing the validity of misogynistic traditions and serves to provide contextual interpretations of these traditions.

Sufism's scientific knowledge extends to gender theories, as well as masculine and feminine theories. For example, the concept of assuraw in al-Maqdur, the concept of isroqiyyah in which Allah explained tahajjul, the attributes of God, turned out to have a feminine nature. The nature of Allah which is ar-Rahman ar-Rahim shows God's compassion, which is feminism, where God's love is unlimited. This illustrates that the mother is full of the nature of God, for example the word womb; that is the nature of God, so it is interesting.

Islam itself, according to As-surawdi al-Maqdur, turned out to be very feminist 
in expressing God's character. The nature of ar-Rahman ar-Rahim are represented by mothers. Therefore, when a mother gives birth she will give love to her child, just like the nature of Allah, the masculinity of God is in the form of creation, not in the nature of God, so that later there will be no refraction of a woman. The nature of God is both feminine and masculine, so it is very appropriate if there is an idea of the formation of a gender curriculum and gender theory.

In the science of Islamic Law, the topic of gender equality can be seen in aspects of family law that discuss the relationship between husband and wife, relations between parents and children, the relation between children and children, especially Islamic jurisprudence courses which are very suitable if integrated with gender equality learning, discussing the relationship between men and women.

Secondly, in education science the topic of gender equality is important to discuss as it is related to the right of both men and women to get the same education. Islamic teachings mention "utlubul ilma minal mahdi ilal lahdi" that for men and women "tolabul ilmi faridotin alal muslim wal muslima"; that means obligatory for Muslim men and Muslim women. In terms of theological doctrine, in fact, Islam, in terms of education, does not limit the movement of women, or equally between men and women. The other important things that must be discussed in class are that there is no dichotomy between men and women in the teaching-learning process.

In Arabic language education, there are various aspects of equality for men and women. For example, the sentence of Assalamu 'Alaikum applies to men and women. Furthermore, Teacher Education Raodhatul Atfal (PGRA) also teaches aspects of child psychology, as well as psychology for male or female adults. However, we learn gender equality if these women and men have different ways of thinking. Gender equality in teaching at PGRA needs both female and male teachers.

The topic of equality and gender injustice can also be reviewed in Biological science, namely about Reproduction of Embryology. Related to this science, there are many people who still hold that discussing reproduction is taboo and not ethical. However, when discussed scientifically, the discussion is the same as with other body organs. In this discussion, women were discussed a lot, so men also had to learn about women's anatomy to increase their knowledge. Furthermore, reproductive subjects or issues such as contraceptive use (KB) or infertility are mostly connected with women 
and affect gender inequality. Even if examined medically, the main cause is not only from women, but men also have a great opportunity as the cause of problems with infertility or reproductive problems. In fact, in reproductive issues, equality is more focused on the perspective of men in understanding women.

Thirdly, in the science of Da'wah, actually there is no dichotomy between men and women. The terms of male and female rights are not different. In the science of communication or Islamic broadcasting, the topic of gender equality is related to gender in the media, such as how to hold a camera where there is no difference between men and women. Men and women can search for news and become news reporters. Women have the same rights in using the media without certain restrictions.

The Science of Community Development also discusses gender equality and justice, such as violence against women and stereotypes or bad images of women, for example in the class there is a separation between men and women. There is a separation between the roles of men and women, their emotional closeness is not so close or there is a partition, for example there is a special bench for women and one for men. In terms of sharing roles and functions, it is often understood that women cannot be equal to men; that is, women should not have a higher position (leadership) than men. For instance, the woman may not become a 'Kosma' or class leader. This is a bad image of women that women are assumed to be really weak. Other examples are the comparison of the concepts of equality of men and women in the perspectives of several religions, the concept of gender and development, the problem of poverty, and the low quality of public facilities that often discriminate against women.

Some other important points related to the integration of science in gender studies, according to the study participants, are several things that need to be added, namely: first, the approach is not normative / textual, but rather contextual and responds to current conditions; second, almost all scientific disciplines cannot stand alone but are also equipped with other values, such as Islamic values and the values of relations between men and women. So, every Islamic perspective is important to be integrated with the values of gender equality. Another thing that needs to be studied further is the scientific perspective in terms of medicine and psychology, because many cases have a lot to do with gender. Similarly, in psychology the it is necessary to explore more aspirations and feeling as a woman; third, the topic of gender equality and scientific 
transformation needs to be emphasized, which aims to create justice for men and women. It is important to eliminate the curriculum that is patriarchal in nature because policies that are not gender biased are needed in various respects, especially understanding the points about Islam, society, culture, and politics in order to read reality using multidisciplinary science.

\section{Gender Learning Design}

There were 5 (five) questions submitted to participants regarding gender learning design. Their descriptions and analyses are as follows:

\section{Gender learning method}

Gender learning can be started for the first time by including material in syllabi or by the existence of special discourse courses related to gender issues, as well as workshops for all lecturers on gender enlightenment; this is so that all parties have the same gender perspective. Include material on gender equality in the syllabus, because in every science there is a gender bias. For example, according to biology men and women are different, where men are more rational and women are more irrational (by looking at the anatomical structure of their brains), which has implications for the withdrawal of the assumption that men are more courageous and women tend to be more timid.

Such character in biology for men and women occurs in a bias that is influenced by a mindset built by a very long culture. This is what affects the observation of living things that someone has a mindset to assess. The image and behavior that is suitable for men and women has been constructed by culture. Because it requires changes to the curriculum or syllabi that have gender justice content and the perspective of the lecturer or teacher must be unbiased. Then the need for discussion from the historical context. The method used is a historical approach or not just textual, because it must also look at the context. For example, the context in which the Qur'an and the Hadith first appeared. After learning about the historical approach, automatically the context will be known and can then be synergized with the current context.

For the teaching method, KKG learning uses multiple methods in the form of lectures, question and answer, discussion, assignments, or role play, so the principle of learning is carried out actively in an innovative, creative, effective, and enjoyable way. 
All learning methods can be used in accordance with the theme, then, by jumping in the field so that you have experience outside the classroom about how practice in the field sees reality, one knows that the community needs to be empowered to develop awareness about the KKG.

The other methods are able to accommodate all learning methods or models that focus on critical thinking. For example, Hadith criticism or misogynistic interpretations (Hadith criticism or gender bias interpretations), literary criticism, song criticism or gender-biased poetry, and airing videos that display gender bias are then analyzed using focused discussion groups (FGDs = focus group discussions). Lecturing also applies in certain situations and conditions, although it must be combined with other active learning methods so that they are not monotonous and boring. In addition to that, the inquiry method can also be applied, namely the method of asking questions followed by questions until students find their own mistakes and truths. Of course, learning through research in daily life also needs to be applied so that students are able to reflect material and the world in reality, it is even expected that lecturers and students can become agents of change for the KKG problems that occur around them.

\section{Stages of gender learning}

The stages of gender learning are first by introducing what gender is, what gender bias is, what gender equality is, and what gender-based empowerment is. There are stages that can be followed to incorporate thoughts so that one word, gender, is necessary in understanding the terms and concepts of the KKG. In the tradition of Hadith, for example, the steps taken are first introducing a gender approach to the method of criticizing Hadith. This is usually carried out by looking at reality, discussion, dissecting the book, comparing the rules of family law with other countries, and so forth.

The application of knowledge is given to all parties and clarifies again that gender issues are important. It is necessary, then, to convey gender theories in a scientific perspective such as Sufism that also speaks of gender, especially as compared to other theories, for example, other gender theories that have developed in the west; thus the reconstruction of the interpretation of women. Women, as leaders, can be judges to decide cases. Of course, the interpretation of the Qur'an and Hadith will not be separated from the asbabun-nuzul ayat and hadith asbabul-wurud. 
Furthermore, workshops and training on the preparation of gender curricula need to be held, and for students there are courses. Other scientific activities in the form of gender seminars are curriculum workshops where the overall output of these activities is a gender curriculum. The discussion then is when, or in what semester, the gender course will be given, and must be able to see the quality or target to be achieved.

The stages and gender learning methods that are appropriate to be applied in the classroom do have to follow the flow of the syntax. As an example of a focus group discussion method, for example, which will discuss "polygamy". Polygamy, according to the film 'The Verses of Love' (based on the novel Ayat-Ayat Cinta), the first stage of the film must be shown in its entirety, or just focus on the important parts, then discussed. Likewise, role play and other methods will provide opportunities for students to understand and reflect on the gender issues discussed.

After the process of understanding the terms and concepts, the next step is to raise the issues that occur in the community and how we react to them, then discuss the methods that will be used. Of course, discussion of what sciences can be used in studying gender equality is very necessary and students can also understand the laws in gender equality in an Islamic perspective, and how to apply them to everyday life.

It is also important to introduce a gender approach to the criticism of Hadith methods, usually done by looking at reality, discussion, dissecting the book, comparing the legal rules of the family with other countries, and others; besides that, learning the history of gender so that it can help people understand what gender is and its application, specifically along with other knowledge, such as the development of motivation, independence, speaking ability, voting rights, and equitable relations for men and women.

\section{Gender learning assignments}

The forms of tasks suggested regarding gender learning can be in the form of paper-making assignments, field studies, case studies, and others. Case studies, for example cases of domestic violence in homes that make women victims. The form of assignments that will be given to students can also be in the form of group discussions on gender inequality topics from various perspectives, or individual assignments about translation from English into Indonesian; for example translating "Culture and Gender"; Barbara Crossette's writing: "Culture, Gender and Human Rights", and Malahtun 
writings: "Culture, Institutions, and Gender Inequality in Latin America" contained in the book Culture Matters: How values form human progress edited by Lawrence E. Harrison and Samuel P. Huntington. Another way is for students to be invited to write essays on gender equality that are suitable for multicultural Indonesian communities by reflecting on the points of the writing that raise the issue of KKG.

As with other courses, gender learning should be more directly involved in the community because we want to change the mindset of people who are gender-biased. Students are also biased about cases that occur in the community or in the form of advocacy activities / accompanying good cases of committing acts of violence that involve male or female.

Moreover, the lectures do not need to only happen in class and it is helpful to find theories among the cases that occur in society. In this case, the lecturer must come along side by side, so that the theory emerges after a case, so that people are expected to become more open, more intelligent, and with a deeper understanding of gender including women's rights.

In practice, in-class methods of discussion or sharing stories and experiences about their respective regions, so that friends can get new perspectives about gender, are quite productive. In the science of interpretation, there is a new method initiated by one of the lecturers, namely the tabaadul method, that focuses on how the texts in the Qur'an must be understood equally, as if the text had told men. Textually the verses call upon women, actually calling on men, as well as vice versa. The verses, or Hadiths, in which the text cursed women meant that they were also cursing men, reflecting a concept of equality. This is very important to be used as a method of gender learning in the classroom. Students were asked to look for verses that were considered to cause injustice, especially in the interpretations of the scholars, then reinterpret the ulema's interpretations in accordance with the present context.

Other important things related to student assignments should be conducting research at home; how the cases that occur are related to gender or gender bias. Most cases occur because of violence, stereotypes, or others that are parts of gender, because the perpetrator has a gender bias; does not know about roles as women and men. Gender contains the division of roles that have been labeled by the community. Furthermore, to be more effective, you should immediately jump into the field, for example in the 
villages. If it is only limited to understanding the texts and theories, that will be in vain; it is also necessary to know how the consequences actually occur in society.

Writing papers, conducting library research, observations, or field study assignments can be expanded in the classroom learning methods through role play, quizzes, film reviews, and other more interesting methods and provide opportunities for students to analyze the KKG problem and find solutions to these problems. In Biology, the tasks given are mostly analyzing the functions of reproductive organs which will be presented using PowerPoint presentations and giving field assignments in the form of counseling to certain communities that still lack knowledge about reproductive health.

Other forms of assignments are portfolios that contain western ideas about the concept of gender equality and justice and what Islamic thinking about gender is, then compiled in a paper. To make a resume or portfolio, of course, the process of reading books, as a whole, is related to gender, observing and analyzing the relations of men and women in family and community life, and looking for texts that support the strengthening of equality of male and female relations.

\section{Expected results (desirable outcomes)}

The desired results include that after we know about the methods and theories, we can apply them to everyday life. The desired point in the learning is that the rights of men and women are the same, both in acquiring knowledge and other sciences.

After students know the importance of gender equality and the solutions, of course students must be able to apply it in their daily lives and also be able to solve people's problems regarding gender inequality. Students must also be able to provide information to the community and their respective regions.

Each person responds so that every social actor has a wiser attitude, a more mature attitude and is more tolerant, so that eventually it creates a social dynamic or a good social event that is not condescending to one another. The desired results related to the science of Floating Islamic Society, namely in analyzing social issues or social problems, are not only fixed on one factor or several factors, but must see the problem as a subject that must be involved fairly.

There are three important domains, namely the attitude, cognitive, and realm of skills that must be developed. From the realm of attitude means the students can socialize, associate, introduce, and continue to implement it, first to themselves, and 
then to the surrounding environment by continuing to possess and master knowledge about gender material, and also from the realm of skills to make something new from what they know; something new about gender issues.

Expectations related to gender learning in the class will have justice between men and women, the second is the formation of an understanding that Islam does not distinguish between women and men. Only one difference is that women give birth to children naturally, women have been given birth and become mothers for their children, but social roles and political roles remain the same. Men also have a supportive role, so there are similar roles and different roles. This different role is not to corner one party, but to create gender justice.

In the science of interpretation, the results to be achieved are the growing awareness of gender equality and the presence of new / gender-oriented speakers. At least students can conduct a review of verses that are considered to discriminate against gender. The results to be achieved are that students can not only study textually, but also examine the social and contextual problems in Islamic law so that a maximum awareness of gender equality can be created.

Related to Biological science, the results to be achieved are: first understanding the subject of reproduction in a way that is no longer taboo. Second, it can inform the smallest amount of knowledge to others so as to prevent reproductive diseases, especially among teenagers. The results to be achieved are good human beings, IAIN graduates, or Islamic Religious Colleges (PTKI) as good teachers, not only good in their studies, but also aware of good values. Students are expected to be aware of their respective roles. If men, their rights and obligations have been established, as well as those for women. Then, they can respect each other's rights and obligations and not force them to cross their nature, but have the courage to express their attitude, to argue, and to think about being able to make progress as one of their forms.

There is a correct understanding, like what conceptual gender really is, both theoretically, conceptually and in the perspective of Islam and national culture. It must be noted about gender discussions in culture such as the role of women in the western world, Indonesian women also play an equally important role.

Changes in the thinking paradigm related to male involvement often consider men to be the source of problems. However, partnership must be discussed, namely 
wisdom in responding to this matter. It does not mean that gender is all a western product, meaning that Indonesian nationality has also been strong, we just need to provide understanding and forms of fair practices for men and women.

Furthermore, the desired result is a new awareness that men and women are actually the same in the role area, must learn from each other, and complete common tasks. Ideally, there is indeed a correct understanding of conceptual gender, both theoretically, conceptually, and from Islamic and national cultural perspectives; understanding the duties and functions of male and female, both personally, within a family, and in the community.

The desired results of gender learning in the classroom, of course, can be elaborated on with the results of knowledge (cognitive), attitudes (attitude, value, affective behavior), and the results of psychomotor skills in a balanced manner. This is not only examined from the side of knowledge only, while the attitude and psychopsychological side are ignored, so it is not corrupt. Learning outcomes must be written in the Semester Learning Plan (RPS) which synergizes the three, for example having knowledge about gender equality must synergize with being gender-equal and treating others fairly and equally. Other learning outcomes can depend on the subject matter and standards of competence and basic competencies.

The results to be achieved are that students can not only study textually, but also examine the social and contextual problems of Islamic law so that a maximum awareness of gender equality can be created. Lecturers and students develop an awareness of how much Islam has given high respect to women and is balanced between western thought and eastern thought, as well.

\section{Other important things in gender learning design}

In macro terms, an understanding of Islam or religious concepts must be addressed. The teachings of Islam are rahmatallilalamin, which considers all human rights to be the same. Historical fact shows that women were second class before Islam came. In fact, Islam has, from the beginning, emphasized that there is no difference in rights between men and women. This must be straightened out so that gender, social 
inequality, and capitalism (this term is actually from the initial concept of Islam) have banned these things.

The gender learning design should first be designed to make the values and principles of gender equality and justice elevate both male and female. The second is that there is no gender bias in employment, in education, and in politics. Women are expected to be able to compete fairly. The $30 \%$ quota mechanism for women in the political arena may be the initial stage.

Furthermore, it must depart from the needs, so it must pass the assessment first, the extent of understanding of students, lecturers, or the community, so as not to fall flat, so the design must depart from the needs first, do not direct needs and focus only on the theoretical. Not everyone has knowledge that is open to something previously considered wrong, so it departs from need. An understanding of those needs was then designed in response, so the possibility of each class was different in its learning design.

As a concrete action, a student center was established where discussions on various issues could take place that could also be field research. As an example, the need for witnesses; why should there be 2 (two) women, on arranged marriages and forced marriages without the knowledge of either party? Both parties must be able to walk together side by side, which means understanding each other and walking side by side, with equality there is no need to fear rivalry.

In the end, the desired result is that after we know about the methods and theories given, we also have to apply them to our daily lives. What is desired in the learning is that the rights of men and women are the same; both in acquiring knowledge and other sciences. In the end, the actions of all elements (officials, staff, lecturers, and students) will contribute to each other and make a tremendous contribution when understanding gender awareness is already underway.

\section{Conclusion}

The development of gender-based curricula is very important to study through teaching, research, and in implementing the Tri Dharma of Higher Education and conducting community empowerment programs. Of course, efforts and high commitment are needed so that these goals can be achieved. Therefore, the awareness, roles, and involvement of the academic community and the community are very crucial in designing methods, efforts to integrate science, and applications within and outside 
the campus environment. Furthermore, cooperation from multiple stakeholders is needed so that the goals of learning and community empowerment can be achieved. The benefits will be felt not only by the academic community, but by the community at large, as well. Of course, this is in line with the Tri Dharma of Higher Education (Education, Research, and Community Service).

\section{References}

Anggraini, Nini. (2007). Kekerasan terhadap Perempuan. Working Paper Sosiologi Vol. IX. No. 4. Oktober 2007. Padang. Laboratorium Sosiologi Fisip Unand Creswell, David. (2003). Research Design, London: Sage Publication Danim, Sudarwan. (2002). Menjadi Peneliti Kualitatif, Bandung: Pustaka Setia Denzin, et al. (2000). Qualitative Research Method, London: Sage Publication Dominelli, L. (2010). Feminist Perspective on Social Work, London: Sage Publication Fakih, Mansour, (1996). Analisis Gender dan Transformasi Sosial, Yogyakarta: Pustaka Pelajar

J. Moleong, Lexy, (2003). Penelitian Kualitatif, Bandung: Remaja Rosda Karya.

Mosse, C. Julia, (1996). Gender dan Pembangunan, Yogyakarta: Pustaka Pelajar. Edisi Bahasa Indonesia.

Mufida, C. (2004). Paradigma Gender, Malang: Bayu Media.

Murniati, A., Nunuk P. (2004). Getar Gender, Perempuan Indonesia dalam Perspektif Agama, Budaya dan Keluarga, Magelang: Indonesiatera

Raoul Wallenberg Institute of Human Rights (2014, 2015). Distributed Materials of A Blended Course of Gender Equality and Human Rights of Women. Kuala Lumpur, Malaysia.

Siddique, Kaukah, (2002). Menggugat Tuhan Yang Maskulin, Jakarta: Paramadina.

Susilaningsih, dkk., (2004). Kesetaraan Gender di Perguruan Tinggi Islam, Yogyakarta, UIN Sunan Kalijaga Yogyakarta dan McGill-IAIN-Indonesia Social Equity Project.

Tim Penulis Pusat Studi Wanita (PSW). 2003. Pengantar Kajian Gender, Jakarta: Universitas Islam Negeri (UIN) Syarif Hidayatullah Jakarta.

Umar, N. (1999). Argumen Kesetaraan Gender. Jakarta: Paramadina 